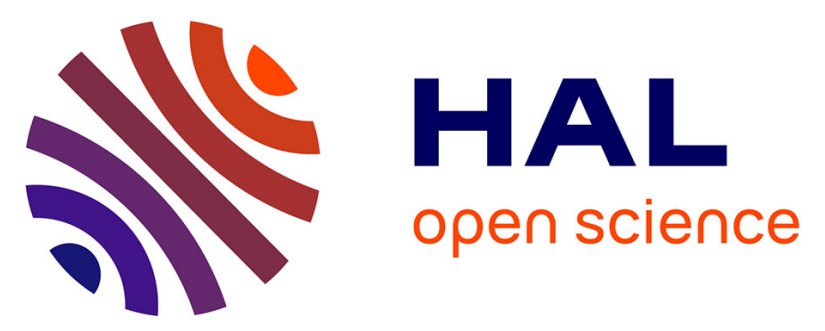

\title{
Horizontal and vertical fluid flows as a key control of ore deposition at the basement/cover unconformity: insight from drone imagery of the Vendée coast, France
}

\author{
Loïc Bouat, Pierre Strzerzynski, Régis Mourgues, Yannick Branquet
}

\section{- To cite this version:}

Loïc Bouat, Pierre Strzerzynski, Régis Mourgues, Yannick Branquet. Horizontal and vertical fluid flows as a key control of ore deposition at the basement/cover unconformity: insight from drone imagery of the Vendée coast, France. vEGU21: Gather Online, Apr 2021, Online, France. 10.5194/egusphere-egu21-15409 . hal-03554474

\author{
HAL Id: hal-03554474 \\ https://hal.science/hal-03554474
}

Submitted on 3 Feb 2022

HAL is a multi-disciplinary open access archive for the deposit and dissemination of scientific research documents, whether they are published or not. The documents may come from teaching and research institutions in France or abroad, or from public or private research centers.
L'archive ouverte pluridisciplinaire HAL, est destinée au dépôt et à la diffusion de documents scientifiques de niveau recherche, publiés ou non, émanant des établissements d'enseignement et de recherche français ou étrangers, des laboratoires publics ou privés. 
EGU21-15409

https://doi.org/10.5194/egusphere-egu21-15409

EGU General Assembly 2021

(c) Author(s) 2022. This work is distributed under

the Creative Commons Attribution 4.0 License.

\section{Horizontal and vertical fluid flows as a key control of ore deposition at the basement/cover unconformity: insight from drone imagery of the Vendée coast, France}

Loïc Bouat ${ }^{1}$, Pierre Strzerzynski ${ }^{1}$, Régis Mourgues ${ }^{1}$, and Yannick Branquet ${ }^{2,3}$

${ }^{1}$ Laboratoire de Planétologie et Géodynamique (UMR6112), Le Mans Université, Le Mans, France (loic.bouat@univlemans.fr)

${ }^{2}$ Géosciences Rennes (UMR6118), Université de Rennes, Rennes, France

${ }^{3}$ Institut des Sciences de la Terre d'Orléans (UMR7327), Université d'Orléans, Orléans, France

Basement/cover interfaces are important transfer zones for hydrothermal fluids responsible for ore deposition, such as $\mathrm{U}$ and $\mathrm{Pb}-\mathrm{Zn}$ deposits. Unconformities are peculiarly mixing zone where basement-derived fluids encounter sedimentary- and/or meteoric-derived fluids; leading to precipitation of these ores. Fluids are channelized by permeability contrast, i.e. impermeable barriers, until being trapped in porous units, i.e. intrinsic porosity and/or secondary porosity (dissolution and karstification process). In this configuration fracturing channelize the fluid flow by breaking impermeable barriers allowing external fluids to enter and react with the rocks (precipitation and/or dissolution). In this way, structural studies are crucial to highlight the fracture network and the potential of geological units to be good reservoirs.

In France, many occurrences of sediment-hosted deposits are known in Mesozoic basins (i.e. Aquitaine and Paris Basin) especially above the Variscan basement (Morvan district, SW Massif Central district, Poitou High district). The Vendée coast deposit (South Armorican Massif, France) is known for two $\mathrm{Pb}-\mathrm{Zn}(-\mathrm{Ag})$ occurrences located in Liassic sediments overlying the Variscan basement. Previous works show that, during the Upper Jurassic extensional event (NNE-SSW horizontal stretching), the ore deposition results from the mixing of two different fluids: (1) low temperature brines following a horizontal path from evaporite to basin borders within Liassic sediments along the unconformity, (2) a high temperature and low salinity fluid rising up through the basement from several kilometres depth by a probable vertical pathway.

However, the permeability architecture leading to such mixing remains poorly constrained. The Vendée ore deposits present favourable outcrop conditions to study the structural control of the fluid plumbing system along the basement/cover unconformity. Structural studies assisted by drone imagery coupled with the characterization of the alteration-mineralization pattern show that:

(1) Horizontal path for basin brines is controlled by the impermeable barrier of the Toarcien layer overlying Liassic hosting karsts. 
(2) Vertical path of basement-derived fluids is enhanced by new faults and inherited fractures, respectively generated and reopened by the Jurassic extension.

(3) Relative abundance of faults and veins in the Liassic sedimentary cover and the basement is consistent with a mechanical decoupling in a context of fluid overpressure. 